\title{
On the Noise Hazard Assessment within the Intermediate Range of the High Audible and the Low Ultrasonic Frequencies
}

\author{
Antoni ŚLIWIŃSKI \\ Institute of Experimental Physics \\ University of Gdansk \\ Wita Stwosza 57, 80-952 Gdańsk, Poland; e-mail: fizas@univ.gda.pl
}

(received March 15, 2016; accepted April 22, 2016)

\begin{abstract}
In parallel to the ultrasonic noise assessment procedures and research activity in the field there have appeared several papers in the domain of so called high-frequency audiometry which covers the range of frequencies $8-20 \mathrm{kHz}$. They are important for recognizing the harmfulness and hazard of the audible high frequency sound components in the same range as the one of the low frequency ultrasonic noise. On the other hand there exists a certain inconsequent situation in the general approach to the problem of ultrasonic noise hazard assessment in work places environment which concerns the convention to include the frequency range of $10-20 \mathrm{kHz}$ to the domain of ultrasonics. The range consists of one third octave bands of central frequencies: 10,12.5, 16, $20 \mathrm{kHz}$ and conventionally is called low frequency ultrasonic noise though at least the components of the two lowest bands are naturally audible by a majority of population (mainly young people). The paper presents a discussion related to some achievements of the two domains and some conclusions which could be useful for a more consequent description of the subject and could be taken into account in the future regulations for the ultrasonic noise assessment in work places environment.
\end{abstract}

Keywords: ultrasonic noise assessment; high frequency audiometry.

\section{Introduction}

In the previous paper (ŚLIWIŃSKI, 2013) related to the ultrasonic noise hazard assessment in work places environment a short discussion had appeared on a certain inconsequent situation in the general approach to the problem that concerns the convention to consider the frequency range of $10-20 \mathrm{kHz}$ to be named as ultrasonics. The range consists of one third octave bands of central frequencies: 10,12.5, 16, $20 \mathrm{kHz}$ and conventionally is called as low frequency ultrasonic noise (LFUN) though at least the components of the two lowest bands are by a majority of population naturally audible. The convention (being in contradiction with the determination of the upper hearing threshold frequency recognized as $20 \mathrm{kHz}$ ) comes from the fact that usually the hazard assessment for the audible noise (AN), with regard to the speech intelligibility and hearing losses (HL), is only performed up to the octave band of the $8 \mathrm{kHz}$ centre frequency. However, independently of the ultrasonic noise assessment procedures and research activity in the field there exists a par- allel domain so called high-frequency audiometry (HFA) which covers the range of frequencies 8-20 kHz. There are papers belonging to the domain which are important for recognizing the harmfulness and hazard of the audible noise above $8 \mathrm{kHz}$ e.g. (PrzekLasa et al., 2008; Mehrparvar et al., 2011; LaWton, 2013; Smagowska, 2015). Among others, the subject of interest of that audiometry is determination of HL appearing due to exposure of noise containing components in that range (such components exist in so called non-technological ultrasonic noise sources (NTUNS) as differentiation to the technological ultrasonic noise sources (TUNS) i.e. active ultrasonic machines and devices working on a given ultrasonic frequency (Smagowska, Mikulski, 2007; MikulSKI, Smagowska, 2007; SmagowsKa, 2012; 2012a; 2013; 2013a; 2013b; Smagowska, PaWlaczYKŁUSZCZYŃSKA, 2013). The HFA results have shown, among others, that the hearing losses appearing at persons working in industry in noise containing high frequency components, are chronically much more in advance than those appearing at persons working only 
in audible noise. However, the general knowledge about the influence of ultrasonic noise components on the human HL is far from satisfaction.

This paper presents a short discussion related to some recent publications (LAWTON, 2001; 2013; Schwarze et al., 2005; PrZeKlasa et al., 2008; Tucker, 2010; Martin, 2011; Mehrparvar et al., 2011; SMAGOWSKA, 2015) as well as some remarks on the terminology and conclusions which could be, perhaps, useful for a more consequent description of the subject and could be taken into account in improving future regulations for the ultrasonic noise assessment in work places environment.

\section{A short review of some recent papers on HFA and LFUN in respect to the noise hazard assessment}

\subsection{High frequency audiometry domain}

Though the high-frequency audiometry (HFA) have a longer history (since 1960 - 70-ties, GRzESIK, PLUTA, 1978) some recent papers brought some new facts which might be useful in the following discussion.

In the final report of the research project on HFA and noise induced hearing losses (NIHL) (SCHWARzE et al., 2005) the authors presented reliable results (supported by statistical multivariate analysis) which have shown that loss of hearing capacity in the HF range could have a predictive value for HL due to noise. The authors have stated that the variance observed of the threshold values (studied as depending on such factors as age, gender, noise exposure history at workplaces during the last 10 years, smoking status and some others) is considerably (more than 2 times) larger in the $\mathrm{HF}$ range than in the deepest frequencies used in conventional audiometry $(\mathrm{CA})$. Although in their conclusions they said: "in general a high interdependence between the HFA and the CA data ... could be shown", but still "the results do not indicate as they can be a useful instrument in early detection of hearing impairment and that the specific loss of hearing capacity might be an indicator of an increased sensitivity to noise". Nevertheless, their results have shown the HFA method as a useful one, though it is "...a difficult, errorprone and time-consuming method...".

The possibility of a predictive value of HFA results for noise HL assessment have also been stated in the following papers: (PRZEKLASA et al., 2008; SingH et al., 2009; Mehrparvar et al., 2011) in which the authors presented a comparison of results obtained applying HFA and CA methods for evaluation of hearing impairment in people exposed to industrial noise.

The authors of the first paper (PRZEKLASA et al., 2008) performed examination for two groups of men before employment and after 8 years of work in the noise environment of continuous and impulse character. Their results showed that in the CA case the changes for $8 \mathrm{kHz}$ were of the order of $10 \mathrm{~dB}$, while for the HFA one the shift was up to $25 \mathrm{~dB}$; also a greater progression was observed in the HFA case. After 8 years, a $>5 \mathrm{~dB}$ hearing threshold shift was observed in $60 \%$ to $76 \%$ of the ears, while for the CA the corresponding value was from few to $36 \%$ of the ears, depending on the frequency. In conclusions they stated: "In people occupationally exposed to noise, the HFA is a sensitive method for monitoring of HL and the HFA allows to detect them earlier than the CA in the situation of presence subclinical changes in the range of frequencies have not made yet felt by a person examined".

In the second paper (SingH et al., 2009) a comparison have been presented between the CA $(0.25-$ $8 \mathrm{kHz})$ results and the HFA $(10-20 \mathrm{kHz})$ ones of hearing thresholds measured in the group of 20 cases with history of exposure to noise and the group of 50 normal healthy subjects. The noise induced hearing losses (NIHL) were detected in the HF range in $62 \%$ of subjects of the first group. among which in the younger age part (10-30 years) $74 \%$ cases could be detected by HFA at the early stage. Thus it was concluded that "ultra high frequencies were useful in detecting early NIHL" and "results confirmed the critical need for auditory threshold monitoring encompassing high frequencies in patients exposed to noise".

The authors of the third paper (MeHrParvar et al., 2011) performed the HFA as well as the CA examinations of workers in two groups: with and without exposure to noise in industrial environment. Comparing the effect of noise on the results of $\mathrm{CA}$ and HFA the authors observed that the hearing threshold in HFA $(16-20 \mathrm{kHz})$ was significantly higher than in conventional frequencies $(250 \mathrm{~Hz}-8 \mathrm{kHz})$. In conclusions they stated: "HFA is more sensitive to detect NIHL than CA. It can be useful for early diagnosis of hearing sensitivity to noise, and thus preventing HL in lower frequencies especially speech frequencies".

A very competent review is presented in the paper of Lawton (LAWTON, 2013) written more than a decade after his previous report (LAWTON, 2001) in which problems about the "exposure limits for airborne sound of very high-frequencies and ultrasonic ones" are presented. The statements of noise limits from around the world are reviewed and the interpretation of existing or proposed band limits are discussed on important aspects of the influence of noise levels, maximum permissible levels (MPL) depending on age, duration of the exposure, noise dose and others, like hearing damage by the noise, concepts of protection, etc. In conclusions, among others, some facts were checked off: 
- in the third octave frequency bands below the $20 \mathrm{kHz}$ the MPL values (established in different countries by government standard bodies) are rather low due to avoid unpleasant subjective effects caused mainly by audible components and not due to prevent a direct influence of ultrasonic ones,

- in the very high audible frequency or ultrasonic frequency bands "the dose-response relation is unknown: most limiting levels have been set low, deliberately to avoid any effect whatever" and

- "at present, the exposure limits lack the sophistication to predict hearing damage and adverse subjective effects caused by sounds outside the customary frequency range for occupational noise exposure assessments".

It is worth mentioning that in the HFA domain in parallel to the examination of airborne sound there are papers related to ultra-high frequencies (and law ultrasonic ones) range on the bone conduction stimulation of the human ear. Some recent results in this field (TUCKER, 2010; MARTIN, 2011) are important to explain more about the mechanism of the general influence of the ultrasonic noise on HL than only airborne ultrasonic examinations.

However, the methods (e.g. based on a direct delivering of acoustic signal via a bone conduction transducer to the mastoid or on otoacoustic emission effect measurements) as well as the special clinical approach to the evaluation of the HL of the human ear present a separate domain. Though there exists many interesting results obtained in the domain for potential applicability in the ultrasonic noise hazard evaluation we will not be able to review them within this paper.

\subsection{Low frequency ultrasonic noise}

Some recent contributions in low frequency ultrasonic noise (LFUN) (RADosz, 2012; 2014; 2015; Smagowska, Mikulski, 2012; Smagowska,
2013; 2013a; 2013b; SmagOWSKA, PAWLACZYKŁUSZCZYŃSKA, 2013). SMAGOWSKA (2015) have shown what the situation exists on the ultrasonic noise hazard and the assessment of its professional risk in selected branches of Polish industry. The results obtained reflect a current diagnosis on the problem of annoyance, harmfulness and professional loss of health in work environment of ultrasonic noise. It is useful to recall some examples of these publications.

In the paper (SMAGowskA, 2013c) the questionnaire survey tests performed for a group of 52 operators of machines manufacturing deck gratings were reported. The noise at their work places contained ultrasonic components created by the non-technological ultrasonic noise sources (NTUNS) characteristic of such machines and devices as using for instance, pneumatic tools, grinders, plasma cutting processors, cutting with acetylene-oxygen torches and gas metal arc welding etc. The author stated that in the group examined "the $92 \%$ of the respondents were exposed to noise permanently and characterized it as: droning, insistent, creaking, whistling and squeaky, whereas slightly fewer people described it as roaring and wheezing. Male respondents unequivocally considered the Sound Pressure Level (SPL - in survey "noise level") at their workplaces as: not nuisance, tolerable, loud, impeding communication, high bothersome and tiring". Figure 1 shows the example of survey results for the workers subjective assessment of the "noise level" at their workplaces. "About $50 \%$ of responses confirmed that "noise level" was: loud, impeding communication, high bothersome and tiring".

Figure 2 presents the survey results for the employees' subjective assessment of the degree of annoyance of the level of noise at workplaces for the production of deck gratings. The following terms received the biggest number of points on the 100 point scale representing the degree of annoyance of noise: horrible, enormous, persistent, and intense.

Interesting results of laboratory tests on determination of the influence of ultrasonic noise on human cog-

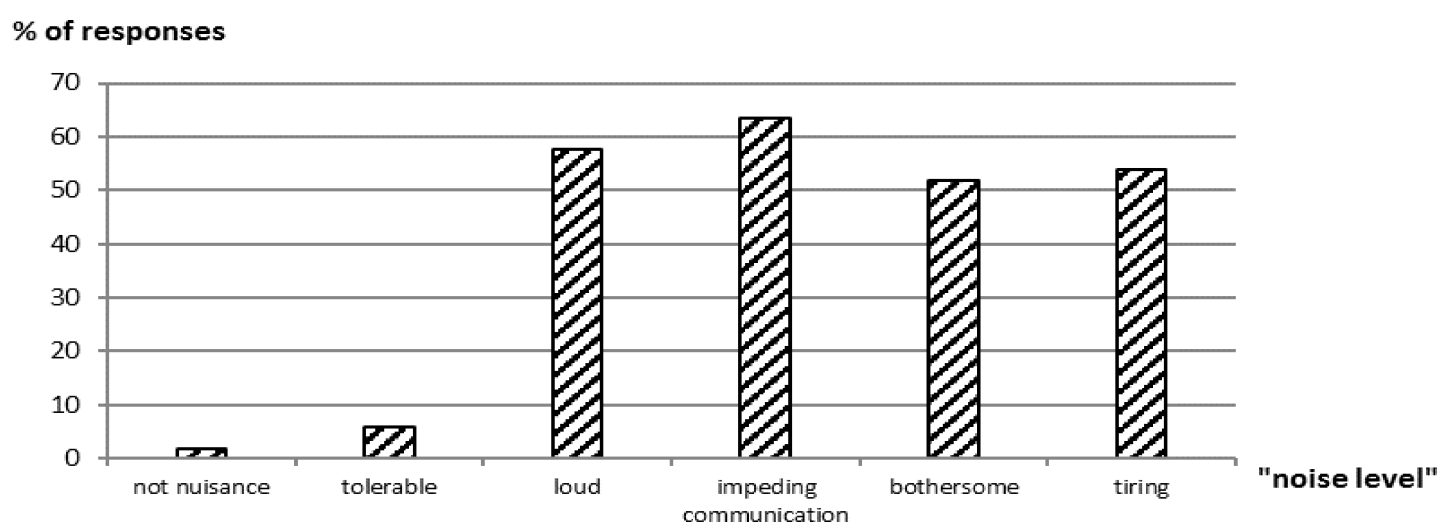

Fig. 1. Employees' subjective assessment of the "noise level" at workplaces for the production of deck gratings (SMAGOWSKA, 2013a; cit. with the author's kind permission). 


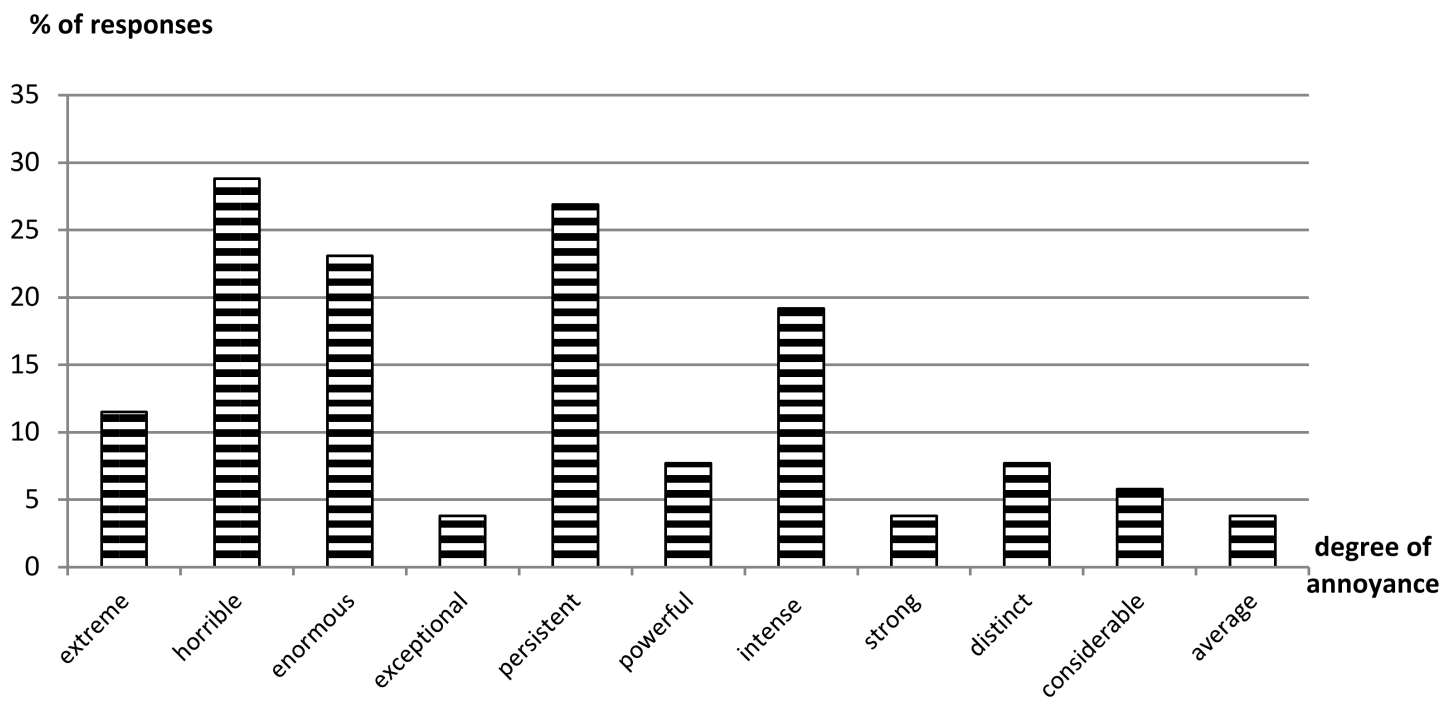

Fig. 2. Employees' subjective assessment of the degree of annoyance of the level of noise at workplaces for the production of deck gratings (SMAGOWSKA, 2013a; cit. with the author's kind permission).

nitive skills and psychomotor capability have been presented in the paper (SMAgowska, Mikulski, 2012; SmagowskA, 2015). Subjective assessment of ultrasonic noise (UN) annoyance were performed using a group of 20 men exposed in different variants of experiment. The UN spectrum of a pink character (example - Fig. 3) covered the three $1 / 3$ octave bands of central frequencies: 25, 31.5 and $40 \mathrm{kHz}$ and the three sound pressure levels (SPL): low SPL (L, $97 \mathrm{~dB}$, medium SPL (M, $103 \mathrm{~dB})$ and high SPL (H, $108 \mathrm{~dB})$ were used for exposures. The four experiment variants were carried on: - without noise exposure and, - under exposure to: low (L), medium (M) and high (H) SPL.

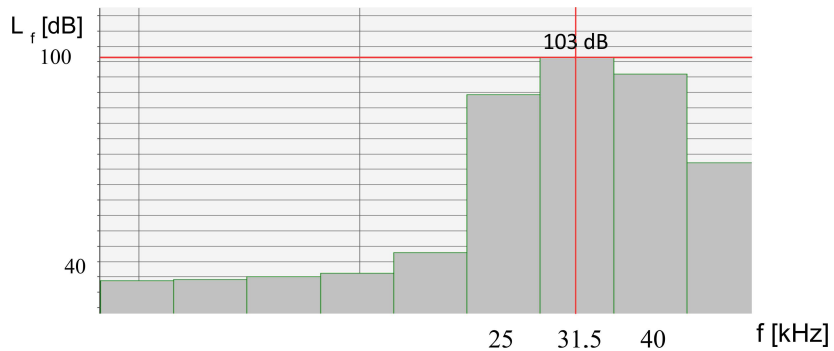

Fig. 3. Ultrasonic noise spectrum of the medium (M) sound pressure level (Smagowska, Mikulski, 2012; cit. with the authors' kind permission).

Examinations took place at the computer stand adapted for the psychological tests. The tests depended on determination of changes in the range of such psychological functions as: reflex, quickness of perception, attention continuity and efficiency of headwork as well as subjective feeling (of mood and tiredness) of subjects tested using both: professional psychological and questionnaire survey tests. A final effect of these particular examinations was the assessment of UN annoyance using the 100 points scale for its filling increase against the SPL. The additional fact in experimental observations was appearing a limit value of unbearable (burdensome) annoyance for the $\mathrm{H}$ level case (and even for the $M$ level case) depending on the $1 / 3$ octave frequency band. Basing on the fact the authors have suggested a preliminary criterion of annoyance of ultrasonic noise determined in the band of $31.5 \mathrm{kHz}$ as about $100 \mathrm{~dB}$. Such criteria could be established for other frequency bands in further research.

A series of examinations were performed at work places of ultrasonic noise sources (UNS) (RADOSZ, 2012; Smagowska, 2012; 2013; 2013a; 2013b; 2015). Among others some results of measurements of sound pressure levels radiated by UNS (e.g. compressor air cleaners (Fig. 4) or ultrasonic washing devices (Fig. 5) have shown appearing of significant values of components up to the band of $40 \mathrm{kHz}$ with increasing tendency what evidenced their presence in the next higher than $40 \mathrm{kHz}$ bands; the Fig. 4 and Fig. 5 present such examples of results limited to that band because the $40 \mathrm{kHz}$ band is the highest of the one third

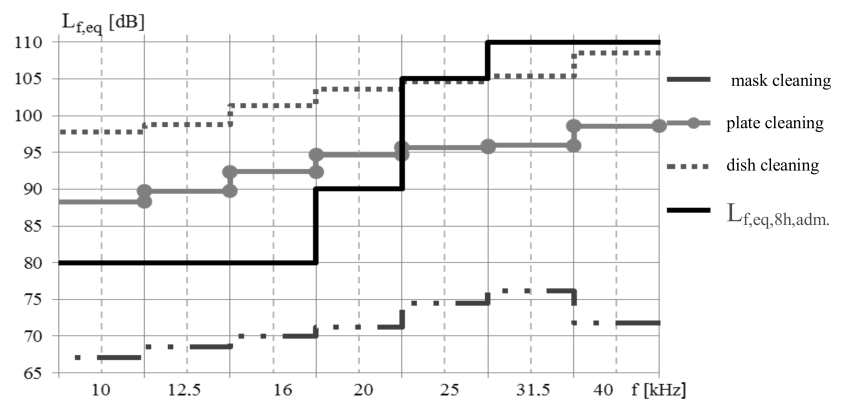

Fig. 4. Measurements results of equivalent sound pressure levels at workstations with cleaning units using compressed air $\left(L_{\mathrm{feq}, 8 \mathrm{~h}, \mathrm{adm}}=\mathrm{MAL}\right)($ SMAGOWSKA, 2013 ; cit. with the author's kind permission). 


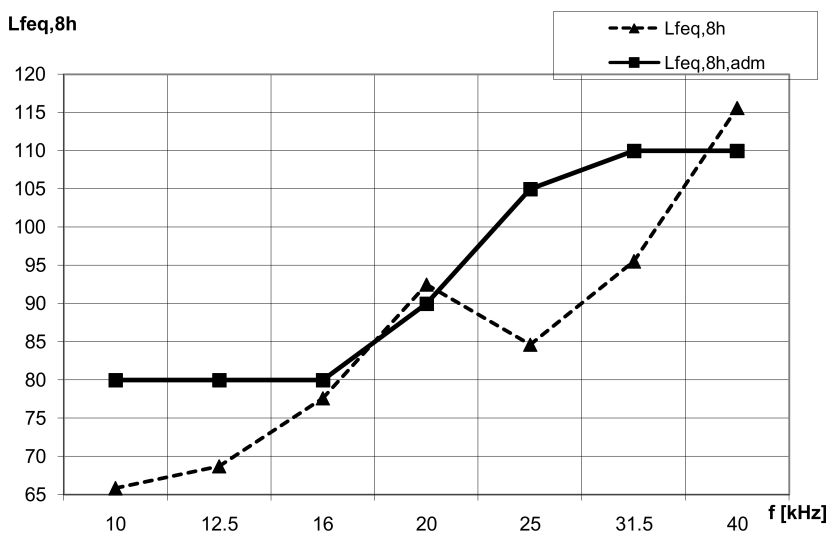

Fig. 5. Measurements results of equivalent sound pressure levels at workstation of ultrasonic washer Sonic 5 $\left(L_{\mathrm{feq}, 8 \mathrm{~h}, \mathrm{adm} .}=\mathrm{MAL}\right)($ SmAGOWSKA, 2015 ; cit. with the author's kind permission).

octave frequency band taken into account in ultrasonic noise assessment procedure determined in Polish legislation (PAWLACZYK-ŁUSZCZYŃSKA et al., 2001; RADOsz, 2015), hence the $40 \mathrm{kHz}$ band is the highest one presented in the figures. The fact of appearing in the ultrasonic noise at some work places components higher than $40 \mathrm{kHz}$ band cause the author (SMAGOWsKA, 2015) to suggest to add two next bands of 50 and $63 \mathrm{kHz}$ to include them into recommendations as required for measurement (see Table 1).

A valuable contributions (RAdosz, 2012; 2012a; 2014) which have effected in elaborating the new procedure for measuring ultrasonic noise (RADOsz, 2015) were related to problems of a proper assessment of hazard of noise of technological sources of impulsive working regime. The particular task of measurement of such noise is to get information about peak values and maximal acoustic pressure levels of impulses as well as about a character of their statistical distributions about the pulse rise time, duration time, decay time and repetition frequency. In measuring practice determination of these quantities and evaluation of a real hazard at a working place may make some difficulties which are for instance connected with uncertainties of evaluation of real (reliable) exposure time according to the procedure of determination of equivalent noise levels of the ultrasonic noise at workplaces (RADOsz, $2012 ; 2012 \mathrm{a}$ ) and also with uncertainties connected with instrumentation and measuring conditions (e.g. position of a microphone and other factors (RADOSZ, 2014) or with a character of acoustic field depending on the source directivity pattern and on reverberation conditions at the measuring place (SLIWINSKI, 2013).

In the new procedure for measuring ultrasonic noise the author (RADOsz, 2015) took into account as stated in the summary: "the analysis results of current legislations to ultrasonic noise in a working environment, methods of measuring noise, metrological requirements for measuring equipment, and identification of factors affecting the measurement result. A new ultrasonic noise measurement procedure was developed on the basis of the results of research conducted in the Central Institute for Labour Protection - National Research Institute. The procedure includes requirements for measuring equipment, periodic metrological control, test environment (temperature, humidity, static measurements. The procedure also includes the use of correction for measuring results and the method of determination of measurement uncertainty in accordance with other acoustic ISO standards".

It is worth to mention that there in the new procedure the definitions of the ultrasonic noise range of 10$40 \mathrm{kHz}$ as well as other general formulations existing in previous regulations (PAWLACZYK-ŁUSZCZYŃSKA et al., 2001) and related to ultrasonic noise measurements procedure adapted from the norms of audible noise have been preserved. The new regulations were accepted by the Polish responsible authorities: Experts Assembly of Physical Factors (Group of Noise) and the Interdepartmental Commission for Maximum Admissible Concentrations and Intensities for Agents Harmful to Health in the Working Environment.

\section{Discussion and terminology proposal}

It is clear from above review that much more research is required in order to have better knowledge to be able to improve existing methods and regulations in future. Taking into account the facts we have considered so far and coming back to the already mentioned paper (ŚLIWIŃSKI, 2013) one can return to the previous discussion suggested in that paper. It is useful to cite one figure from the paper (Fig. 6).

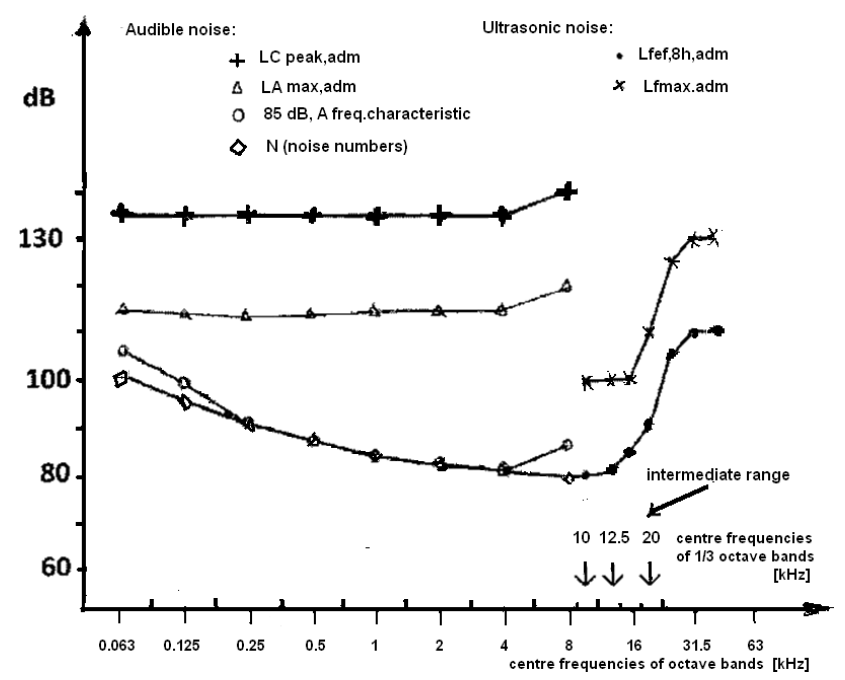

Fig. 6. A comparison of the curves for evaluation of admissible values for audible noise and for ultrasonic noise at work places $L_{\mathrm{fe} .8 \mathrm{~h} . \text { adm }}$ and $L_{\mathrm{fmax} . \mathrm{adm}}$, respectively (cit. ŚLIWIŃSKI, 2013) with several alterations. 
Table 1. Proposals for the Ultrasonic Noise terminology.

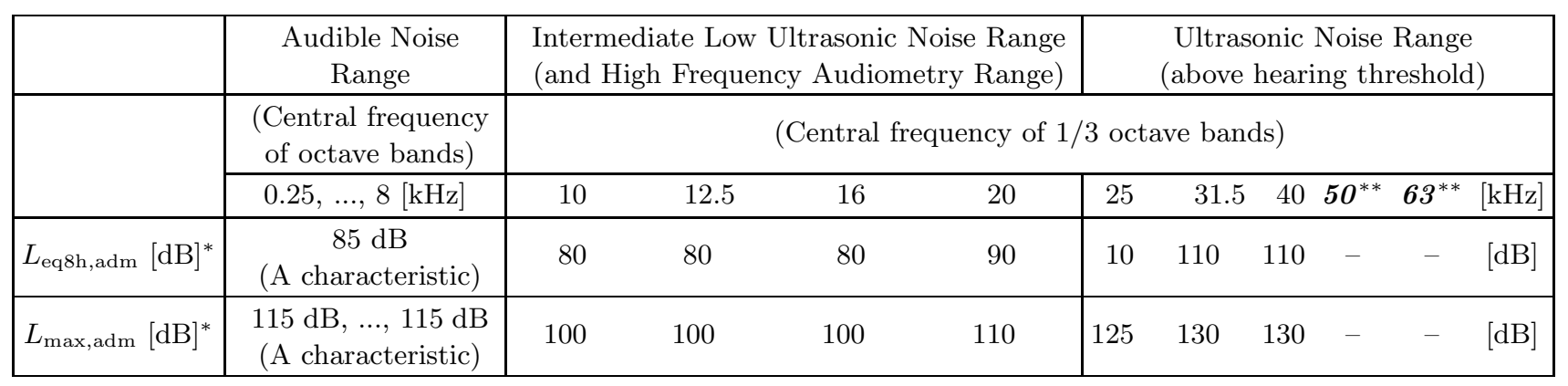

* after (PAWLACZYK-ŁUSZCZYŃSKA et al., 2001),

** after (SMAGOWSKA, 2015).

In the figure for comparison a few curves are shown presenting admissible (AD) and maximal admissible levels (MAL) determined in standards for noise assessment: for audible noise (LCpeak.adm, LAmax.adm), $85 \mathrm{~dB}$ according to the A frequency characteristic and $\mathrm{N}$ - noise rating numbers) as well as the corresponding curves for the ultrasonic noise range $\left(L_{\text {feq.8h.adm }}\right.$, $L_{\text {fmax.adm }}$ ); the lowest curve is the total curve used in the whole range for evaluation when the noise spectrum contains both the audible as well as the ultrasonic components. It is useful to mention that the LCpeak.adm and LAmax.adm curves for audible noise are presented in octave frequency bends what is a practical approximation with regard to the original curves corresponding to the case of tonal noise components.

Also, in the figure the "intermediate" range is marked as the range of $10-20 \mathrm{kHz}(20 \mathrm{kHz}$ corresponds to the upper hearing threshold frequency); according to previous suggestion my proposal is to treat that frequency range of $10-20 \mathrm{kHz}$ as the "intermediate" one (in fact overlapping with the HFA range), i.e. to treat that range as exclusively separate on the whole noise frequency scale and to name it as "intermediate audible-ultrasonic range" Legitimacy of the above claims is supported by such arguments as the physical phenomena occurring within the range which have its own characteristics (even its own research domain: HFA) and practical experience. So, for instance achievements and results of HFA could be used to elaborate its own procedure for assessment of noise in this intermediate range. As a final consequence of considerations and analysis of the facts reviewed above the summarizing Table 1 of proposals for the ultrasonic noise terminology is presented. The entire frequency scale of noise consists of three ranges which are: Audible Noise Range, Low Ultrasonic Range (overlapped with the High Frequency Audiometry Range) and the Ultrasonic Noise Range. In the two lower lines the values for the $L_{\text {eq } 8 \mathrm{~h}, \text { adm }}$ and $L_{\text {max,adm }}$ are given according to the Polish regulations (PAWLACZYK- ŁUSZCZYŃSKA et al., 2001; RADOsZ, 2015).
In addition, according to the Smagowska's suggestion to add the frequency bands of 50 and $63 \mathrm{kHz}$ (SMAGOWSKA, 2015) they are put in the table (in bold italic) but there is a lack of the values for $L_{\text {eq } 8 \mathrm{~h}, \text { adm }}$ and $L_{\text {max,adm }}$ which could be expected to determine in the future. It is worth mentioning that the proposal to add next two bands of 50 and $63 \mathrm{kHz}$ to the Ultrasonic Noise Range would require discussion supported with much more measurement results and examinations in the ultrasonic noise sources in industrial environment.

Since two years the regulations of UN assessment in Poland have been replaced by new recommendations (RADOsz, 2015) and other activities are being continued in Central Institute of Labour Protection - Research Institute, Poland to elaborate and to approve the future changes in standards for assessment and evaluation of ultrasonic noise in work environments. Perhaps the proposals presented here would be worth to take into consideration.

\section{Conclusions}

The short review of the few recent papers and their results given above has clearly shown the strong interdependence between two research domains (i.e. HFA and LUN ones).

Achievements of both domains of overlapping frequency range are important for our knowledge of proper assessment of noise within the range and for improving recommendations and regulations in regard to the ultrasonic noise protection procedures in industrial environment.

Considerations and some proposals presented in the paper on the general terminology could be, perhaps, useful for a more consequent description of the subject and could be taken into account in the future improvements in regulations. It is worth mentioning that the first similar suggestion to separate the intermediate audible-ultrasonic range $(10-20 \mathrm{kHz})$ and pure ultrasonic one above $20 \mathrm{kHz}$ was put by (GRzesik, Pluta, 1978) many years ago. 


\section{Acknowledgments}

The author is grateful to the Central Institute of Labour Protection - National Research Institute in Warsaw, particularly to the ultrasonic noise Group of the Department of Vibroacoustics for the long and effective cooperation during many years.

\section{References}

1. Grzesik J., Pluta E. (1978), Assessment criteria and health examination of ultrasonic devices service persons [in Polish: Kryteria oceny oraz badanie stanu zdrowia osób obstugujacych urzadzenia ultradźwiękowe], Materials for Studies \& Research [Materiały do Studiów i Badań], 43, 30-40, CIOP, Warszawa.

2. LaWton B.W. (2001), Damage to human hearing by airborne sound of very high frequency or ultrasonic frequency, Health and Safety Executive Contract Research Report 343/2001, HSE Books, Sudbury, ISBN 0717620190.

3. LAWTON B.W. (2013), Exposure limits for airborne sound of very high frequency and ultrasonic frequency, ISVR Technical Report No: 334/2013, Univ. Southampton, Southampton SO171BJ

4. Martin J.A. (2011), Bone-Conducted Ultrasonic Hearing: Can Distortion Product Otoacoustic Emissions Confirm Cochlear Involvement?, Master's Thesis Chalmers Univ. of Technology, Göteborg, Sweden.

5. Mehrparvar A.H., Mirmohammadi S.J., GhoReyshi A., Mollasadeghi A., Loukzadeh Z. (2011), High frequency audiometry: A means for early diagnosis of noise-induced hearing loss, Noise \& Health, 13, $55,402-406$.

6. Mikulski W., Smagowska B. (2007), The method of professional risk related to ultrasonic noise [in Polish: Metoda oceny ryzyka zawodowego zwiazanego z halasem ultradźwiękowym], Bezpieczeństwo Pracy, 3, 13-17.

7. Pawlaczyk-€uszczyńska M., Koton J., ŚliwińSKa-Kowalska M., Augustyńska D., KameduŁA M. (2001), Ultrasonic noise; Documentation of proposed permissible values of professional risk levels [in Polish: Hałas ultradźwiękowy; Dokumentacja proponowanych wartości dopuszczalnych poziomów narażenia zawodowego], Podstawy i Metody Oceny Środowiska Pracy, 2, 28, 55-88.

8. Przeklasa R., Reroń E., Wiatr M., Skeadzień J. (2008), A role of high frequency audiometry in hearing loss assessment of persons exposed on idustrial noise [in Polish: Rola audiometrii wysokich częstotliwości w ocenie ubytku stuchu u osób narażonych na działanie hałasu przemystowego], Otolaryngologia, 7, 4, 202-206.

9. Radosz J. (2012), Methodology issues of ultrasonic noise exposure assessment, Noise Control Eng. J., 60, $6,645-654$.
10. Radosz J. (2012a), Influence of measurement method on acoustic pressure level values determination in the range of 10-40 kHz [in Polish: Wptyw metody pomiaru na wyznaczanie wartości poziomu ciśnienia akustycznego na stanowiskach pracy w zakresie 10-40 kHz], Mater. XL Szkoły Zwalcz. Zagroż. Wibroakust., Szczyrk, 242-249.

11. Radosz J. (2014), Uncertainty due to instrumentation for sound pressure level measurement in high frequency range, Noise Control Eng. J., 62, 4, 186-195.

12. Radosz J. (2015) Procedure of ultrasonic noise measurements [in Polish: Procedura pomiaru hatasu ultradźwiękowego], Podstawy i Metody Oceny Środowiska Pracy (PIMOŚ), 4, 86, 169-190.

13. Schwarze S., Notbohm G., Gärtner C. (2005), High frequency audiometry and noise induced hearing loss. A contribution to prevention by early diagnosis of a vulnerable hearing?, Publ. Series from the Federal Institute for Occupational Safety and Health-Research Report-Fb 1063, Dortmund/Berlin/Dresden, 2005.

14. Singh R., Saxena R.K., Varshney S. (2009), Early detection of noise-induced hearing loss by using ultrahigh frequency audiometry, IJ Otorhinolaryngol., 10.

15. Smagowska B., Mikulski W. (2007), A method of rough ultrasonic noise identification at workplaces [in Polish: Metoda wstepnej identyfikacji hałasu ultradźwiękowego na stanowiskach pracy], Proc. 54th Open Sem. of Acoust, Rzeszów-Przemyśl, 180-181.

16. Smagowska B., Mikulski W. (2012), Laboratory tests on the influence of ultrasonic noise on human cognitive skills and psychomotor capability [in Polish: Badania laboratoryjne wptywu hałasu ultradźwiękowego na funkcje poznawcze i sprawność psychomotoryczna człowieka], Bezpieczeństwo Pracy, 5, 24-26.

17. Smagowska B. (2012), Ultrasonic noise hazard prevention at work environment [in Polish: Profilaktyka narażenia na hałas ultradźwiękowy w środowisku pracy], Podst. i Met. Oceny Środ. Pracy, 2 (72), 5-11.

18. SmagowskA B. (2012a), Sources of ultrasonic noise at work environment [in Polish: Źródla hałasu ultradźwiękowego w środowisku pracy], Mater. XL Zim. Szk. Zwalcz. Zagr. Wibroakust., Gliwice-Szczyrk, 27.022.03.2012.

19. Smagowska B. (2013), Ultrasonic Noise Sources in a Work Environment, Archives of Acoustics, 38, 169176.

20. Smagowska B. (2013a), Objective and subjective study of noise exposure in the frequency range from $10 \mathrm{kHz}$ to $40 \mathrm{kHz}$, Archives of Acoustics, 38, 4, 559-563.

21. Smagowska B. (2013b), Study on the annoyance of high frequency noise at industrial workstations ICA 2013, 2-6.06.2013, Montreal, Canada, Abstract: Journ, Acoust. Soc. Am., 133, 5 Pt.2 of 2, p. 3503. 
22. Smagowska B., Pawlaczyk-Łuszczyńska M. (2013), Effects of action of ultrasonic noise on the human body - a bibliographic review, International Journal of Occupational Safety and Ergonomics (JOSE), 19, 2, 195-202.

23. Smagowska B. (2015), Identification of emergencies and professional hazard assessment of ultrasonic noise impact in selected industrial branches [in Polish: Identyfikacja zagrożeń i ocena ryzyka zawodowego hałasem ultradźwiekowym w wybranych gatęiach przemystu], Ph. D. Thesis, CIOP-BIP, Warszawa.
24. ŚliwińsKi A. (2010), Physical aspects of an assessment of ultrasonic noise impact on human body, XVth Conf. Noise Control, Książ, p. 1-12.

25. ŚliwińsKi A. (2013), Assessment of ultrasonic noise hazard in work places environment, Arch. Acoust. 38, 243-252.

26. Tucker K. (2010), Critical Review: The efficacy of ultra-high frequency bone conduction stimulation for the treatment of tinnitus, Univ. West. Ontario School of Communication Sciences and Disorders. 